\title{
NEW RECORD OF THE PARASITOID WASP MONODONTOMERUS OBSCURUS WESTWOOD, 1833 (HYMENOPTERA, TORYMIDAE) IN IRAQ
}

\author{
M. S. Abdul-Rassoul* and T. T. Mahmoud** \\ *Iraq Natural History Research Center and Museum, University of Baghdad, \\ Baghdad, Iraq \\ **Department of Plant Protection, College of Agriculture, Dohuk University, \\ Dohuk, Kurdistan Region-Iraq \\ *Corresponding author: msabr_1942@yahoo.com
}

\section{ABSTRACT}

This article reveals the first record of the parasitoid wasp, Monodontomerus obscurus Westwood (Hymenoptera, Torymidae) from Iraq. A total of 27 specimens were emerged from mud nests of sphecoid wasp of Sceliphron sp. (Hymenoptera, Sphecidae), that collected from a wall at a residential garden in Dohuk province. A short morphological description is presented.

Keywords: Dohuk, Iraq, Monodontomerus obscures, Parasitoid, Sphecoid wasp.

\section{INTRODUCTION}

Monodontomerus obscures Westwood, 1833 (Hymenoptera, Torymidae) was first described by Westwood (1833) from Britain; it is now widely distributed in the Palaearctic, Nearctic, Neotropical and Oriental regions (Grissell, 1995; Zerova and Seryogina, 2002; Noyes, 2017). In the Palaearctic region, it was recorded from the following countries: Azores, Bulgaria, Croatia, Czech Republic, Denmark, Egypt, France, Germany, Hungary, Iran, Israel, Italy, Kazakhstan, Lebanon, Macedonia, Moldavia, Netherland, Romania, Russia, Slovakia, Spain, Sweden, Switzerland, Turkey, Turkmenistan, Ukraine, United Kingdom and Central Asia; Nearctic: Canada, United State of America; Neotropical: Chile; Oriental: India and Pakistan (Noyes, 2017).

M. obscures is gregarious parasitoid reared from cocoons and larvae of different species of Coleoptera, family Curculionidae; Diptera, family Stratiomyiidae; families Hymenoptera: Apidae, Chrysididae, Diprionidae, Sphecidae, and Vispidae; Lepidoptera, family Gelechiidae, Lymantriidae and Tortricidae (Noeys, 2017). It is reported in the Palaearctic region from the following hosts: Hoplitis (Hoplitis) adunca (Panzer, 1798) and Osmia rufa (Linnaeus, 1758) (Hymenoptera, Megachilidae) in France (Steffan, 1952); from Eumenes pomiformis (Fabricius, 1781) (Hymenoptera,Vespidae) in the nest of Chlicodomas sp. (Family, Megachilidae) and from Sceliphron destillatorium (Illiger, 1807) (Hymenoptera, Sphecidae), in Italy (Bouček, 1970); from Megachile willughbiella (Kirby,1802) (Hymenoptera, Megchilidae) in Denmark (Holm and Skou, 1972); Xylocopa fenestrata (Hymenoptera, Anthophoridae) in India (Sihag, 1992). 
New Record of the Parasitoid Wasp Monodontomerus obscurus

The reported Nearctic hosts include: Osmia cornuta (Latreille, 1805), O. lignaria Say, 1837 and alfalfa leafcutter bee, Megachile rotundata (Fabricius, 1787) (Family, Megachilidae) (Grissell, 1995). Recently Gözüaçık and Şimşek (2015) reported M. obscures from larvae of the cereal weevil, Pachytychius horrdei (Brulle, 1832) (Coleoptera: Curculionidae) in Turkey.

M. obscures has not been recorded from Iraq until now; however, it is present in two neighboring countries; Turkey (Oncuer, 1991) and Iran (Lotfalizadeh and Gharali, 2005), and now we are presenting here for the first time the occurrence of this parasitoid species in Iraq from specimens have been recently obtained from mud nests of sphecoid wasp, Sceliphron sp. from Dohuk province.

\section{MATERIALS AND METHODS}

A total of 15 mud nests of sphecoid wasp, Sceliphron sp. (Hymenoptera, Sphecidae) were collected. The nests were found in sheltered places attached to electrical wires and walls in residential garden during the month of May, 2013 and 2014 in Dohuk province north of Iraq; these nests were taken to the laboratory and placed in plastic boxes in order to get either the adult sphecoid wasp or the parasitoid. The emerged adult parasitoids were kept in vials containing ethanol alcohol $75 \%$ for the purpose of identification.

\section{RESULTS AND DISCUSSION}

Examination of the specimens, which was conducted by the first author, revealed the presence of an unidentified species of the genus Monodontomerus in Iraq; according to the literature available, keys and descriptions given by Gahan (1941), Zerova and Seryogina (2002) and Grissell (1995), this species is identified as M. obscures Westwood, 1833. This result is considered as the first record of this parasitoid in Iraq.

\section{Diagnosis:}

The M. obscures Westwood, 1833 can be separated from the other species of Malar furrow with a combination of the following characters:

Frenal area of scutellum with fine striation on smooth shiny background. Ovipositor as long as gaster. Fore wing at least somewhat infumate around stigma. Inner hind tibial spurs with different length. Punctured border line of scutellum apex not interrupted medially. Hind femoral tooth represented by more or less acute spine. Antennal scape in both sexes slender (not expanded). Lower margin of clypeus straight. Malar furrow present and complete; face flat or nearly so, at least not markedly swollen. Propodeum laterad of median depression very weakly sculptured, practically smooth; eyes conspicuously pilose.

\section{Description:}

A short morphological description is given here based on the Iraqi specimens for easy identification.

Female (Pl. 1): Body length 3.0-3.5 mm plus 2.5-3.0 mm ovipositor (together 5.5-6.5 mm). Body color dark green to blackish green; antenna with scape testaceous, darker toward apex; pedicel brownish; flagellum black; coxae and femora blackish tined with green, tibiae and tarsi reddish; wings hyaline, with a weak infuscation around, veins brown.

Gaster black, base beneath often more or less testaceous, tergite dorsally slightly greenish, ovipositor sheaths black. Head from above: width and length in ratio 9:4; head in frontal view: width: height ratio about 6:5, moderately clothed with white whitish hairs, face transverse in outline ; malar furrow present and complete; clypeus straight; eyes conspicuously pilose. 
Antennal scape subcylndrica, nearly reaching to lower margin of anterior ocellus; pedicel a little less than twice as long as wide; ring segment about two-third as wide as long; first funicular segment subequal in length to pedicel but distinctly thicker, a little longer than wide; other segments of funicle subquadrate and not wider than first; club as wide as funicle and about as long as two preceding segments combined.

Thorax with parapsidal grooves sharply impressed; scutellum distinctly longer than wide, punctured border line of scutellum apex not interrupted medially, frenal area of scutellum with fine striation on smooth shiny background. Propodeum laterad of median depression very weakly sculptured, practically smooth. Fore wing: costal cell above with complete row along anterior margin, below with 1 to 2 complete setae rows along anterior margin; stigma somewhat squarish, stigma vein faintly stained around stigma; postmarginal vein twice as long as stigma, hind femur about 3 times as long as wide, hind femur tooth triangular; inner hind tibial spur of different length. Gaster longer than thorax, and ovipositor as long as gaster.

Male (Pl. 2): Body length 2-4 mm. Similar to female, except that antenna with dark scape, first funicular segments not longer than wide, other funicular segments more transverse slightly wider than long; gasteral tergites short.

\section{Materials examined}

Dohuk 14우, $3 \hat{\jmath} \widehat{\jmath}$ May.2013, and 2014 ex. Mud nest of Sceliphron sp.

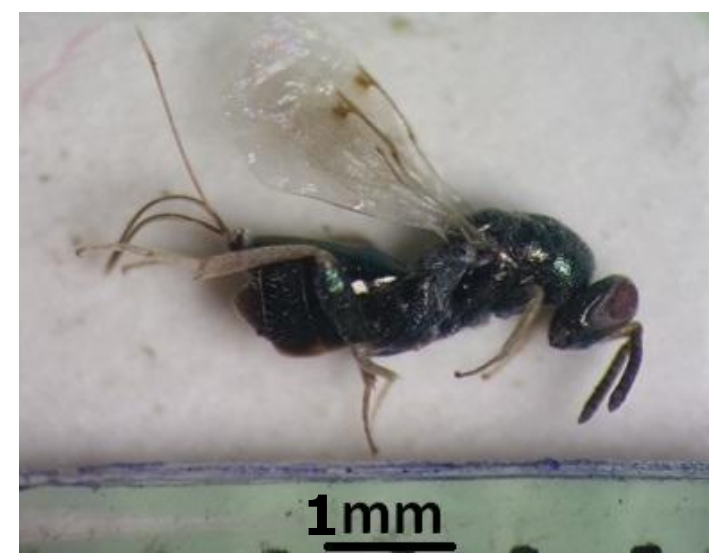

Plate (1): Female of M. obscurus 
New Record of the Parasitoid Wasp Monodontomerus obscurus

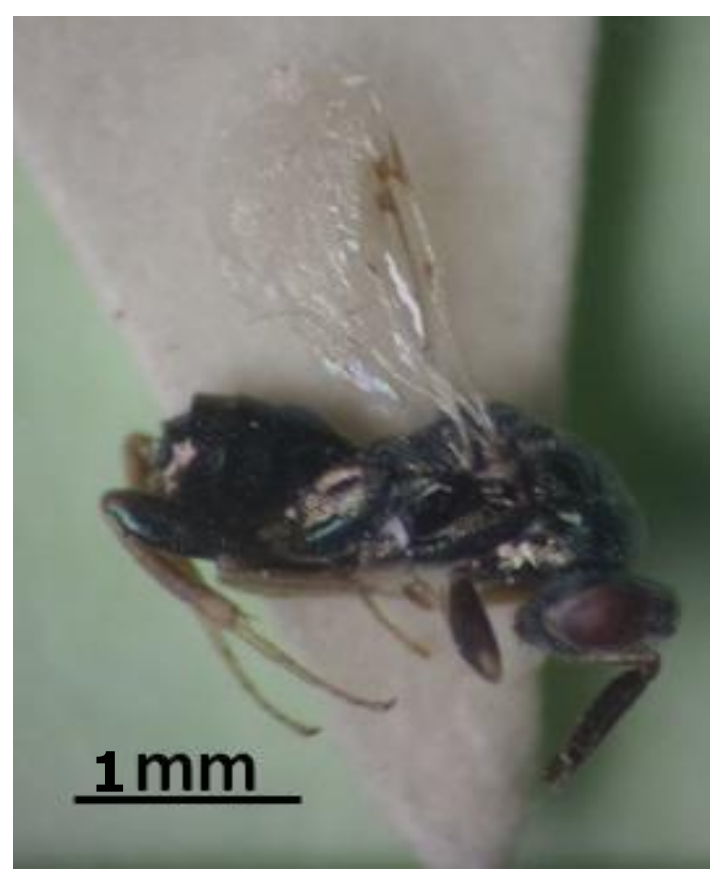

Plate (2): Male of M. obscurus

\section{ACKNOWLEDGMENTS}

I would like to express my sincere thanks to my colleague Prof. Dr. Razzaq Shalan Augul of Iraq Natural History Research Center and Museum for his help in photographing the specimens.

\section{LITRETURE CITED}

Bouček, Z. 1970. Contribution to the knowledge of Italian Chalcidoidae based mainly on a study at the Institute of Entomology in Turin, with description of some new European species (Hymenoptera). Memorie della Societa Entomologica Italiana, 49: 35-102.

Gahan A.B. 1941. A revision of the chalcid-flies of the genus Monodontomerus in the United States National Museum. Proceedings of the United States National Museum, 90: 461-482.

Gözüaçık, C. and Şimşek, Z. 2015. Larval parasitoids of the cereal weevil, Pachytychius hordei (Brulle, 1832) (Coleoptera: Curculionidae) at Mardin province in Turkey. Egyption Journal of Biology Pest Control, 25(1): 7-10.

Grissell, E.E. 1995. Toryminae (Hymenoptera: Chalcidoidea: Torymidae): a redefinition, generic classification and annotated world catalog of species. Memoirs on Entomology, International, 2: 474pp. 
M. S. Abdul-Rassoul and T. T. Mahmoud

Holm, S. N. and Skou, R. 1972. Studies on trapping nesting and rearing of some Megachhile species (Hymenoptera: Megachilidae) and on their parasites in Denmark. Entomologica Scandinavica, 3: 169-180.

Lotfalizadeh, H. and Gharali, B. 2005. Introduction to the Torymidae fauna( Hymenopter: Chalcidoidea) of Iran. Zoology in the Middle East, 36: 67-72.

Noyes, J. S. 2017. Universal Chalcidoidea Database. World wide web electronic publication. (Available at: http://www.nhm.ac.uk/chalcidoids) (accessed 22nd Nov. 2017).

Oncuer, C. 1991. A catalogue of the parasites and predators of insect pests of Turkey. Ege Universitesi Ziraat Fakultesi Yaynlar, 505: 354 pp.

Sihag, R.C. 1992. Behavior and ecology of the subtropical carpenter bee, Xylocopa fenestrate F. 4. Parasites, predators nest destroyers. Indian Bee Journal, 53: 30-33.

Steffan, J. R. 1952. Note sur les especes europeen nes et norda fricaines du genere Monodontomerus Westw. (Hym.: Torymidae) et leurshotes. Bulletin du Museum National d'Histoire Naturelle, Paris (2), 24(3): 288-293.

Westwood, J.O. 1833. Descriptions of several new British forms amongst the parasitic hymenopterous insects. Philosophical Magazine, 2(3): 443

Zerova, M. D. and Seryogina, L.Y. 2002. A revision of old world Monodontomerus (Hymenoptera: Chalcidoidae: Torymidae), pp. 33 Separate issue, National Academy of Sciences of Ukraine I.I. Schmalhausen Institute of Zoology, Kiev . 
New Record of the Parasitoid Wasp Monodontomerus obscurus

Bull. Iraq nat. Hist. Mus.

(2017) 14 (4): 329-334

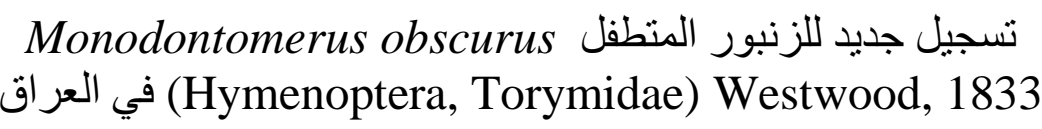

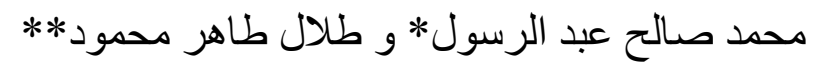

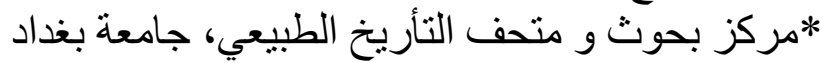

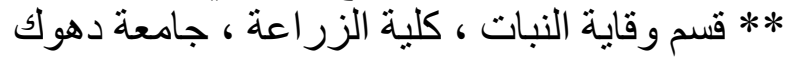

تاريخ القبول: 2017.12.27

2017.12.10: تاريخ الاستلام

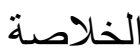

Monodontomerus obscurus Westwood, سجلت الدراسة الزنبور المتطفل

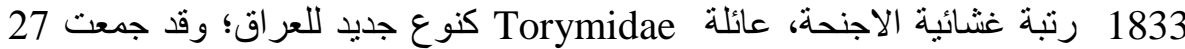
عينة من الطفيلي من أعشاش الطين لزنبور . Sceliphron sp من رتبة غشائية الاجنحة، عائلة Sphecidae ؛ التي تم جمعها من جدار في حديقة سكنية في محافظة دهوك. زودت النتائج بوصف مختصر لاهم الصفات التشخيصية للنوع اعلاه. 